\title{
Tomaž Onič
}

University of Maribor

Faculty of Education, Department of English and American Studies

\section{Translating Recurrences in Pinter's Plays}

\author{
Summary
}

Certain elements of language often repeat in all genres and at all levels of formality, whether spoken or written. This phenomenon, either premeditated or applied intuitively, always has a reason, despite the fact that the speaker (or writer) is not necessarily aware of it.

A re-appearance of a certain word or word cluster is called recurrence. According to various definitions, it can be the direct repetition of a textual element which has appeared before in the text, the re-appearance of a certain word in the form of a different part of speech, or the repetition of a word cluster in which at least some elements of the original sentence repeat in the same or similar form. The term repetition is not used because only seldom is a repetition of a part of a text a real repetition, carrying exactly the same meaning potential of the repeated phrase as did its first appearance. This element of language is often disregarded in translation. It's importance is even greater in texts where recurrences are common or, as in Pinter's plays, they represent one of the important elements of the author's style. Hopefully, this paper will raise awareness of how important it is to consider this element in translation.

Key words: translation, drama, drama translation, recurrence, Harold Pinter

\section{Prevajanje ponovnih pojavitev v Pinterjevih dramah}

\section{Povzetek}

Ponavljanje nekaterih jezikovnih elementov je v večji ali manjši meri prisotno v vsakem besedilu, ne glede na njegovo zvrst, stopnjo formalnosti ali druge karakteristike. Avtor lahko ta fenomen uporablja z namenom, da doseže določene učinke na sprejemnika, ali pa naključno, vendar ponovitve $\mathrm{v}$ vsakem primeru vplivajo na celostno podobo besedila. onovna pojavitev (angl. recurrence) je v strokovni literaturi najpogosteje definirana bodisi kot ponovitev nekega dela besedila v nespremenjeni obliki, lahko gre za ponovitev določene besede s spremembo besedne vrste, ali pa se ponovno pojavi besedni sklop, v katerem se vsaj nekaj elementov ponovi v enaki ali nekoliko spremenjeni obliki. Izraz ponovitev se za omenjeni jezikovni pojav ne uporablja, saj so le redke ponovne pojavitve besed ali besednih sklopov prave ponovitve z enakim pomenskim potencialom. Ponovne pojavitve so v prevajalski praksi pogosto prezrte. Še posebej pomembno jih je ohranjati $\mathrm{v}$ besedilih, kjer so le-te pogoste, ter $\mathrm{v}$ primerih, ko predstavljajo pomemben gradnik avtorjevega sloga. To utemeljuje in s primeri ilustrira tudi pričujoči članek.

Ključne besede: prevajanje, drama, dramski prevod, ponovna pojavitev, Harold Pinter 


\section{Translating Recurrences in Pinter's Plays}

\section{Introduction}

In poetic as well as common every day language certain parts of text or speech often appear more than once. This phenomenon may be either premeditated or applied randomly as a result of intuition. In both cases, it produces a certain potential effect and conveys the conscious or subconscious intention of the speaker.

\section{Definition of recurrence}

Beaugrande and Dressler $(1988,54)$ define recurrence as a direct repetition of a textual element which has appeared before in the text. They do not call it repetition because, according to Beaugrande $(1991,18)$, only seldom is the repetition of part of text a real repetition. Such absolute recurrence, as he calls it, would have to carry exactly the same meaning potential of the repeated phrase as did its first appearance. In most cases, that does not happen, as it is usually the very intention of the speaker that causes the recurrence:

Saying the same thing over again normally carries a context-sensitive message, such as approval, insistence, anxiety, doubt, surprise, or irony. /.../ thus, recurrence is typically an instance of "incremental recursion", where the repeated event adds to the value of the original (Beaugrande 1991, 18).

Green $(1968,22)$, too, is sceptical about the reason for absolute recurrences. She believes that the sentence in which the same thing is said twice in the exactly same way (e.g. John ran home and John ran home) is senseless and unacceptable as it lowers the level of informativeness.

A less strict variation of recurrence is partial recurrence, defined by Beaugrande and Dressler $(1988,54-5)$ as the re-appearance of a certain word in the form of a different part of speech. As such, it is similar to polyptoton, a figure of speech that is defined as "repetition of the same word in various inflected forms" (Kos 1987, 185). In a later article, Beaugrande (1991) defines recurrence as the repetition of a word cluster that does not repeat as a whole; not even all the elements need to repeat. It suffices that some elements of the original sentence repeat in the same or a sufficiently similar form. Some partial recurrences originate in language system functions and are random; others appear as a result of the writer's or speaker's intention:

Some language elements recur simply because they are frequent in the language repertory and form small or closed sets of useful options, e.g., articles, conjunctions, and prepositions. Other elements recur deliberately because the speaker wishes to point back to some previous utterance(s), and are noticeable because they are much less frequent or constrained within small sets (Beaugrande 1991, 19). 
Recurrences can appear on various levels of the text. Numerous authors, e.g. Harris 1952, Van Dijk 1969, Weinrich 1972, and others, deal with special types of recurrence, but the most frequent is lexical recurrence where a word or a cluster of words is repeated. This type is quite easy to notice as it appears on the textual level; it is enough to read or hear the text to perceive it. This article mostly deals with the latter type of recurrence because it applies directly to translation analysis.

\section{Pinter's recurrences}

The frequency of recurrences in plays by Harold Pinter proves that they are an important element of his style (see Hribar 2004, 197). Therefore it is vital that as many as possible are preserved in translation. Sometimes this is a demanding task, especially because recurrences cannot be treated separately from other elements in the text. It often happens that rhythm, length of words, register, rhyme and similar elements need to be considered simultaneously. In practice the ideal situation, when all the characteristics of the original text are incorporated in the translation, seldom exists. More frequently the translator is forced to sacrifice one or more layers of the original, and it is important that those partially or completely omitted should be those which harm the translation the least. Needless to say, to be able to do that, the translator must be well acquainted with the original text. What is more, he or she must be able and willing to spend the time and energy to do this.

Pinter's characters sometimes repeat whole phrases or sentences, sometimes with slight changes, which almost always indicate a change in the speaker's intention. The repeated passage either follows its first appearance closely, or can be delayed for a few lines - or sometimes pages. In general, the most noticeable recurrences for the audience are those which consist of many repetitions, contain unusual words or phrases attracting our attention, or consist of closely repeated passages. So, it is most important for at least some of these to be preserved in translation.

Below, this point is illustrated with an excerpt from Pinter's The Caretaker and its translation by Janko Moder. As the comparison shows, some of the recurrences have been at least partly preserved, but many others have simply been lost during the process of translation.

This example from the beginning of the play is a dialogue between Davies, a homeless tramp, and Aston, a slightly mentally retarded craftsman, who feels sorry for the tramp and takes him home. The audience learns what has happened before the play started. Davies talks a lot, trying to explain to Aston or rather persuade him of the cause of an incident at a café:

DAVIES. Comes up to me, parks a bucket of rubbish at me tells me to take it out the back. It's not my job to take out the bucket! They got a boy there for taking out the bucket. I wasn't engaged to take out buckets. My job's cleaning the floor, cleaning up the tables, doing a bit 
ASTON. Uh.

of washing-up, nothing to do with taking out buckets!

He crosses down right, to get the electric toaster.

DAVIES (following). Yes, well say I had! Even if I had! Even if I was supposed to take out the bucket, who was this git to come up and give me orders? /.../ (Pinter 1977, 18)

DAVIES. Stopi $\mathrm{k}$ meni, postavi predme kanto za smeti in mi reče, nej jo odnesem. Ni moja stvar nosit kante ven! $\mathrm{Za}$ to imajo druzga. Nisem bil vzet, da bi nosil ven kante. Jaz sem za ribanje po tleh, za pospravljanje z miz, mejčkeno za pomivanje, niti slučajno pa ne za odnašanje smeti!

ASTON. Saj.

Odide na desno v ospredje po pražilnik.

DAVIES (raca za njim). No, pa recimo, da bi bil! Tudi če bi bil! Tudi če bi bil vzet za kante, ampak kje je tisti bog, ki lahko stopi predme in mi ukaže. /.../ (Pinter 1990, 4)

The phrase to take out the bucket, with its grammatical structure slightly varied, appears five times, four of those times in one sole utterance. This repetition is not coincidental. It brings out Davies's urge to divert Aston's thoughts from exploring what the real conflict was about. Davies gives him no time to think or reply but keeps talking. The more he talks about taking out the bucket, the more he makes Aston and the audience doubt his story.

The linguistic packet, taking out the bucket, also replicates the task package for Davies. His contention is that tasks are divided, that taking out the bucket is a discrete task unit - one which does not fall into his job description. His repetitions contain a funny mixture of certainty and uncertainty about whether taking out buckets might not, after all, be his task. At the same time, the recurring phrase reveals a good portion of the speaker's contempt for this task assignment, which he obviously considers inferior.

A deeper meaning of this part of the text is also strongly supported by the carefully polished sound effects of several consecutive recurrences.

In the Slovene translation the repetitive effect is almost completely lost. The translator replaced the original phrase taking out the bucket with five different translations: nej jo odnesem, nosit kante ven, da bi nosil ven kante, za odnašanje smeti and če bi bil vzet za kante. These versions more or less meet the criterion of preserving the content, but they certainly fail to maintain the form. Any resemblance among the translations is too vague for the audience to be able to grasp them as chain of recurrent phrases with only slight variations. What is more, such considerable differences also diminish the carefully constructed 
rhythmical effect by using either words of different length or varied word order, both of which create a different rhythm. My suggested translation of this passage preserves the relevant elements to a greater extent ${ }^{1}$ :

DAVIES. Pride tja $\mathrm{k}$ meni, postavi kanto za smeti pred mene pa mi reče, naj jo nesem ven. Ni moje delo, da bi nosil kanto ven! Saj imajo mulca, da nosi kanto ven. Jaz nisem tam, da bi nosil kante ven. Moje delo je, da čistim po tleh, počistim z miz, malo pomivam, ne pa da nosim kante ven!

ASTON. Uh.

\section{Odide na desno v ozadje po opekač.}

DAVIES (mu sledi). No, pa recimo, da bi bil! Tudi če bi bil! Tudi če bi naj tam nosil kante ven, kdo pa je on, da bo prišel tja in mi dajal ukaze?

In my translation, the phrase nosit kante ven is used consistently; it even takes into consideration the minor grammatical variations that appear in the original text. The idea of Davies's characterisation through his repeating the same sentence over and over is much better preserved.

Moreover, the above suggestion also corresponds better to the original as far as rhythm and length of words are concerned. Each phrase, take out the bucket and nosit kanto ven, contains three stressed syllables and keeps this characteristic throughout the passage despite the grammatical variations. There is further acoustic resemblance between the key words of both phrases; the original bucket and the translation kanta are two-syllable words with the stress on the first syllable. They also both contain the $k$ and $t$ sounds and that constitutes the same kind of consonance in both versions. In addition to the consonance, there is a similar degree of resemblance between out and ven.

Apart from the iterative effect, the word cluster take out the bucket will - especially to an English speaking audience - provoke a disturbing echo of the colloquial expression to kick the bucket (i.e. die). The Slovene language does not have a similar phrase, so this dimension of meaning is not included in the suggested translation.

There are at least four more examples of recurrences in the above cited passage, but these are less prominent, especially in the presence of the one commented upon. Only one of those has been preserved in translation, and that is Davies's second utterance (Pinter 1977, 18):

"Yes, well say I had! Even if I had! Even if I was /...l",

which is translated as:

"No, pa recimo, da bi bil! Tudi če bi bil! Tudi če bi bil vzet /.../ (Pinter 1990, 4)".

1 It must be mentioned that in the suggested translation, there are also some changes that do not directly relate to repetitions and recurrences. By including these, I wanted to propose a translation that preserves content and form of the original text as much as possible. 
The phrase, my job, that appears twice in Davies's first utterance is translated as moja stvar the first time and is hidden in the phrase jaz sem $z a$ the second time. The translation moje delo is better because it not only preserves the recurrence but is also connected to the above discussion of taking out the bucket; it stresses the fact that Davies understands this "low job" as something that is somebody else's job. By disregarding the recurrence my job, the translation fails to bring out this feature more explicitly.

None of the three appearances of the pronoun me from the beginning of Davies's first utterance is preserved in Moder's translation. Even my translation only manages to preserve two - the reason being in the differentiation between the longer stressed and shorter unstressed forms of personal pronouns that do not exist in the English language. A larger portion of the joint effect of this recurrence lies in the first two that are accentuated; despite the fact that the third one is formally the same as the first two, it is slightly less noticeable because the stress is on the adjacent verb tells. A similar effect is achieved in my translation, where the first two are replaced by the longer forms meni and mene and manage to keep the connection, whereas $m i$ is too weak and is - like the English me - almost lost. The suggested translation is therefore closer to the original than Moder's, which interrupts the recurrence with the second form predme. Apart from that, pred mene is also more appropriate from the point of view of register, since it sounds less formal.

Another partial recurrence in this passage is cleaning followed by the slightly prolonged form cleaning up. Even though the phrasal verb clean up can according to the English-Slovene Dictionary (Grad et. al. 1990, 147-8) be translated as pospraviti, it is better to use the translation počistiti, i.e. počistim in this case, not so much because of the meaning, but because of the form that resembles the preceding one cistim, the Slovene prefix po-being a substitute for the English up. This choice of words in the translation sounds better than gerunds ribanje and pospravljanje.

\section{Conclusion}

Microstructural comparison of the original and its Slovene translation has revealed some plans where the translator did not consider multiple, significant elements of style that are crucial especially in the case of Pinter. Recurrence is one feature that does not disturb with its absence but does substantially enrich the translation when it is preserved. The ideal situation in which all the layers of the original text would be taken into consideration and then adequately translated is not easy to achieve. Some factors are beyond the translator's control; sometimes, for instance, a word to cover all aspects of a certain passage does not exist. However, it is almost always possible to reach an optimal solution that captures more than just the lexical, semantic, discursive, etc. meaning. 


\section{Bibliography}

Beaugrande, R. de. 1991. Coincidence in Translation: Glory and Misery Again. Target 3, no. 1: 17-53.

Beaugrande, R. de, and W.U. Dressler. 1988. Introduction to Text Linguistics. Harlow: Longman.

- - -. 1992. Uvod v besediloslovje. Prev. A. Derganc in T. Miklič. Ljubljana: Park.

Grad, A., R. Škerlj \& N. Vitorovič. 1990. Veliki angleško-slovenski slovar. 1990. Ljubljana: Državna založba Slovenije.

Green, G. 1968. On ,too' and ,either' and not just ,too' and ,either' either. Fourth CLS: 22-39.

Gülich, E., and W. Raible, eds. 1972. Textsorten. Frankfurt: Anthenäum.

Harris, Z. 1952. Discourse Analysis. Language, no. 28: 1-30, 474-94.

Hribar, D. 2004. Harold Pinter in Slovene Translation. ELOPE, 1, nos. 1-2: 196-208.

Kos, J., ed. 1987. Literatura. Leksikon Cankarjeve založbe. Ljubljana: Cankarjeva založba.

Pinter, H. 1990. Hišnik. (Trans. J. Moder, unpublished manuscript.) Prešernovo gledališče Kranj.

Pinter, H. 1977. Complete Works: Two. New York: Grove.

Van Dijk, T. 1969. Sémantique structurale et analyse thématique. Lingua, no. 23: 28-53.

Weinrich, H. 1972. Thesen zur Textsortenlinguuistik. In E. Gülich and W. Raible, eds., 161-9. 